Illinois State University

ISU ReD: Research and eData

Theses and Dissertations

7-19-2021

\title{
Phenomenal Women and Their Sexualization in Media
}

Tyvon Devontae Lesure

Illinois State University, thetyvonlesure@gmail.com

Follow this and additional works at: https://ir.library.illinoisstate.edu/etd

\section{Recommended Citation}

Lesure, Tyvon Devontae, "Phenomenal Women and Their Sexualization in Media" (2021). Theses and Dissertations. 1450.

https://ir.library.illinoisstate.edu/etd/1450

This Thesis is brought to you for free and open access by ISU ReD: Research and eData. It has been accepted for inclusion in Theses and Dissertations by an authorized administrator of ISU ReD: Research and eData. For more information, please contact ISUReD@ilstu.edu. 


\section{PHENOMENAL WOMEN AND THEIR SEXUALIZATION IN MEDIA}

TYVON D. LESURE

26 Pages

This documentary thesis deconstructs the representation of women in media and culture. Women's sexuality is explored, presenting a deeper understanding of contemporary discourse regarding hyper-sexualization. The film maintains a feminist approach by offering primacy to various women and their unique experiences. A more complex understanding of different perspectives provides a greater outlook on the entire concept of sexualization. Furthermore, this documentary interacts with culture and media as means to understanding the hyper sexualization of womanhood. The documentary certifies that womanhood is not a monolithic experience. Finally, it is argued that women should be in control of the various narratives pertaining to womanhood and women's sexuality.

KEYWORDS: sexualization; male gaze; objectification; subjectification; intersectionality 


\title{
PHENOMENAL WOMEN AND THEIR SEXUALIZATION IN MEDIA
}

TYVON D. LESURE

\author{
A Thesis Submitted in Partial \\ Fulfillment of the Requirements \\ for the Degree of \\ MASTER OF SCIENCE \\ School of Communication \\ ILLINOIS STATE UNIVERSITY
}


Copyright 2021 Tyvon Lesure 


\section{PHENOMENAL WOMEN AND THEIR SEXUALIZATION IN MEDIA}

TYVON D. LESURE

COMMITTEE MEMBERS:

Brent Simonds, Chair

Lauren Bratslavsky

Andrew Ventimiglia 


\section{ACKNOWLEDGMENTS}

First and foremost, I would like to thank Dr. Brent Simonds for his help throughout this entire process. His patience with me was extremely helpful. I greatly appreciate him for allowing me to use his personal camera equipment to film. He has taught me a lot throughout the making of this thesis. Thank you, Dr. Lauren Bratslavsky for educating me and opening my eyes to the world of post-feminism in COM 462. Without your guidance, I would not have pursued this topic. Thank you, Dr. Andrew Ventimiglia for your insight in storytelling and documentary filmmaking, as well as the casual conversations about films. I greatly appreciate your recommendations of documentaries and Fellini films. Thank you to Dr. Nate Carpenter for his help with the CIC lab in Fell Hall. I could not have completed this project without you. Thank you, Abby Bueter, Ashonti Phillips, Regina Sanders, Jennifer Zheng, and Leia Atas for your participation in this documentary. I appreciate all of you deeply, and you have each helped me become a better man. Finally, thank you to my friends and family for your help throughout this process. This has been the hardest thing I have every achieved in life. I would not have completed this without the support of: Sharonda Brown (my mom), Austin Whisnant, Kylie Musslewhite, Bill Borowski, and Becky Fletcher. Thank you all for helping me complete this documentary thesis. My accomplishments are nothing without you. 


\section{CONTENTS}

Page

ACKNOWLEDGMENTS

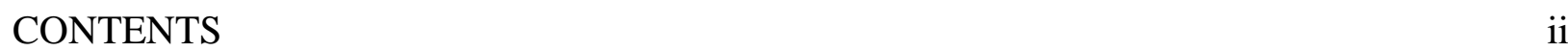

CHAPTER I: SIGNIFICANCE

CHAPTER II: LITERATURE REVIEW

$\begin{array}{ll}\text { Sexualization } & 6\end{array}$

$\begin{array}{lr}\text { Objectification } & 8\end{array}$

$\begin{array}{ll}\text { Subjectification } & 10\end{array}$

$\begin{array}{ll}\text { Race and Womanhood } & 12\end{array}$

Representation of Women in Minority Groups 14

$\begin{array}{ll}\text { Conclusion } & 15\end{array}$

$\begin{array}{ll}\text { CHAPTER III: TREATMENT } & 17\end{array}$

$\begin{array}{ll}\text { The Introduction } & 17\end{array}$

$\begin{array}{ll}\text { Objectification } & 18\end{array}$

Objectification of Women of Color 18

$\begin{array}{ll}\text { Subjectification } & 19\end{array}$

$\begin{array}{ll}\text { Conclusion } & 19\end{array}$

$\begin{array}{lr}\text { REFERENCES } & 20\end{array}$

APPENDIX: THE NARRATION 24 


\section{CHAPTER I: SIGNIFICANCE}

This documentary focuses on the sexualization of women in western culture as it relates to the media and concepts such as objectification and subjectification. In the documentary, a man (the filmmaker) traverses the narratives that represent women in media. A feminist perspective is taken to analyze and deconstruct the meaning behind sexualization. Race is addressed as an individual concept that contributes to the representation of women. Moreover, the documentary seeks to define and contextualize subjectification and objectification. Discourse regarding sexualization is explored to decode the unique perspectives experienced by individuals based primarily on race and gender. Finally, the documentary seeks to understand the relationship between media and sexualization.

The documentary prioritizes women's sexuality, because the portrayal of women throughout media has been centered around their sexuality. Women have been treated as subservient toward patriarchal ideologies. Men have been purveyors of women's sexuality. They control the narrative by eliciting imagery in media that hypersexualizes women. Women are typically seen in roles that portray them in scantily clad clothing or yearning the male gaze with promiscuity. Camera's often focus on women in a manner that mimics the male gaze. Moreover, discourse on women's sexuality has generally been suppressed and undermined. Understanding sexualization provides a positive consideration for women as a marginalized group in western culture. The goal of understanding sexualization is to subvert the objectification of women in media. Rationalizing the sexualization of women based on their own experiences and discernment provides the opportunity for compassion and growth. In laymen's terms, a woman's experience of sexualization is unique, and should be explored for the purpose of social equity and respect. 
Beyond the ethical and cultural significance of the documentary, the documentary is personal. I decided to traverse the topic of women's sexuality and the sexualization of women in media, because of a conversation with my mom. The topic stems from hearing the song WAP by Megan Thee Stallion and Cardi B. Upon listening to the song, I recognized that both artists were receiving flack for their portrayal of women's sexuality. As a male, I do not understand the disdain for the sexual liberation of womanhood. Contrarily, my mom recognized that Black women specifically have a history of being oversexualized in media. Upon further looking into the sexualization of women in media, I realized that the issue was more significant than the song. From my perspective, women's representation in media can be characterized as oppressive. This topic matters to me, because I believe that media representation affects our understanding of reality. Moreover, I believe that the harmful stereotypes we see in media are detrimental for our relationships in the real world. The negative stereotypes we see in media carry over into reality. For example, the fetishization of Asian women in media contributed to the string of 2021 Atlanta Spa shootings, as the killer had a sexual addiction that included a fetish of Asian women. Traversing and counteracting harmful narratives of womanhood in media can potentially stifle the hatred and hardships some women face in reality. 


\section{CHAPTER II: LITERATURE REVIEW}

A feminist lens is used within the documentary. However, post-feminism is used to traverse the topic of women's sexuality. Post-feminism is a perspective in feminism that shifts from preconceived notions of femininity. The understanding of post-feminism places emphasis on the historical shift from second-wave feminism to post-feminism (Gill, 2007a). The film reifies the transition from feminism of the past to feminism of the present and future. Postfeminism has also been associated with the rise of third-wave feminism (Gill, 2007a). The implications behind 'post' in 'post-feminism' places emphasis on the relocation of feminist principles toward newer principles of culture, politics, and history (Brooks, 1997). Some scholars argue that the 'post' in 'post-feminism' certifies that 'the contemporary moment is 'past' feminism" (Projanksy, 2001, p. 66). In this sense, post-feminism is understood as an entity that is independent of feminism. The film disagrees with this understanding of post-feminism. The film frames post-feminism as an extension of feminism. Furthermore, it is argued that post-feminism aligns with the concept of post-modernism, because it delves into the disruption of fixed notions related to gender, as well as authoritative principles related to gender (Gamble, 2004). A few fixed notions are discussed throughout the film. In the film, women from minority groups deconstruct fixed stereotypes they have experienced. Ashonti, Regina, and Jenn offer examples of stereotypes that they have encountered. They challenge these stereotypes by presenting progressive portrayals of women in their racial groups. Conversely, the misogynistic portrayals of women in media are disrupted. Through the guise of post-feminism, the film challenges preconceived notions related to womanhood. It is argued that post-feminism is merely an extension of feminism that connects with other feminist perspectives (Lewis, 2014). Butler (2013) stated "post-feminism also draws on a vocabulary of individual choice and 
empowerment" (p. 43). Throughout the film, women denounce terms that are attached to emerging womanhood. Terms such as "fast," which attacks the promiscuity of young women are criticized. Terms that serve to suppress women's sexuality serve as codes which men and women displace upon womanhood. These codes are a form of language that seeks to oppress women. Deconstructing codes and language of oppression affords further primacy to the experiences of individual women.

A key message within the film is that womanhood is not monolithic. McRobbie (2004) reaffirmed the concept of female individualization by stating that individuals now self-monitor and have a greater ability to plan out their own lives. As an epistemological understanding, postfeminism is seen as a divergence from a focus on equality (Gill, 2007a). Post-feminism places emphasis on the discourse related to differences (Gill, 2007a). Throughout the documentary, womanhood is understood from the different perspectives of White women, Black women, and Asian American women. Emphasis is placed on their different experiences. The concept of equality is used through imagery; however, it is used to represent contemporary social movements. Essentially, post-feminism prioritizes a conversation regarding the different experiences of womanhood. It challenges the notion that womanhood is monolithic. Throughout the documentary, womanhood is understood from the different perspectives of White women, Black women, and Asian American women. Emphasis is placed on their different experiences. In the film, Regina mentions that womanhood is not monolithic. She stated that women do not have the same experiences. Despite not sharing the same experiences as other women, Regina asserts that there is no invalid experience regarding womanhood.

Critics of post-feminism argue against its helpfulness in the pursuit for gender equality. Murray (1997) argued that post-feminism disengages women from activism by placing a focus 
on differences between women. Murray (1997) elaborated by stating that the postfeminist notion of difference "recognizes that women have different needs, but then deprives them of a common commitment to end female oppression" (p. 37). Moreover, Faludi (2009) asserted that the media, specifically the press has cultivated the "postfeminist generation" (p. 11). The documentary disagrees with the critiques of post-feminist. Rather, it showcases how a post-feminist stance can motivate women to improve their own representation by controlling the narrative. Post-feminism is interpreted as a movement that does not care about the equality that feminism pursues (Faludi, 2009). The interpretation assumes that the 'post' in 'post-feminist' pushes beyond caring about the pursuit for gender equality (Faludi, 2009). Critics of post-feminism assert that post-feminism assumes that gender equality is a justified goal that has already been achieved (Jordan, 2016). Contrarily, none of the main characters in the film argue that equality has been achieved. Rather they are arguing for a form of women's representation that is redefined. Post-feminist scholars argue that much of the criticism toward post-feminism is merely backlash discourse (Gill, 2007a). Post-feminism is characterized as more than anti-feminist sentiment (Gill, 2007a). There is a larger context attached to post-feminism that shows both disdain and support for pre-existing feminist ideologies. The documentary positioned for the use of post-feminist by directly challenges preconceived structures that men have placed. Moreover, it challenges feminism by representing unique perspectives of womanhood.

The film takes the post-feminist perspective as a framework to deconstruct harmful stereotypes women face in media. Gill (2007a) stated that post-feminism is a sensibility. Postfeminism is recognized as more than an epistemological perspective, or as a historical shift (Gill, 2007a). Under the guise of a sensibility, "post-feminist media culture should be considered our critical object" (Gill, 2007a, p. 254). Throughout the documentary, media is evaluated as means 
of betterment for women's representation. The post-feminist sensibility is understood as an ideology from which gender can be traversed (Riley et al., 2017). It is a tool for understanding gender and the different experiences that are attached to gender. As a sensibility, post-feminism regards the critique of media and culture. According to Gill (2007b), scholars of culture should be involved in the critique of media. It is not exclusively an analytical perspective. Essentially, post-feminism can be used as a "theoretical framework for understanding discourse in contemporary series, some recent character representations, and the corresponding cultural atmosphere" (Lotz, 2001, p. 106). The frame of reference for post-feminism is skewed toward social, cultural, and political areas that may exist in conflict with feminism (Genz \& Brabon, 2009). There are essential themes that are encompassed within a post-feminist discourse (Gill, 2007b). These themes include:

"The notion that femininity is a bodily property; the shift from objectification to subjectification; the emphasis upon self-surveillance, monitoring and discipline; a focus upon individualism, choice and empowerment; the dominance of a makeover paradigm; a resurgence in ideas of sexual difference; a marked sexualization of culture; and an emphasis upon consumerism and commodification of difference" (Gill, 2007b, p. 149). Gill (2007b) followed up by asserting that these themes intersect with inequalities based on race, ethnicity, gender, sex, class, and disabilities. Post-feminism is a myriad of concepts related to the identity of women. Finally, through characterizing their unique experiences and their opinions on women's sexualization in media, the main characters use a post-feminist perspective.

\section{Sexualization}

Sexualization places an emphasis on sex and sexuality. The sexualization of culture conceptualizes a transformation in western societies in which pornography and oversaturated 
sexual representation have gained influence on modern culture (Harvey \& Gill, 2011). The documentary engages women who acknowledge their oversexualization in media. The main characters of the documentary give examples of women being oversexualized in media.

Precisely, the sexualization of culture refers to "the extraordinary proliferation of discourses about sex and sexuality across all media forms, as well as to the increasingly frequent erotic presentation of girls', women's and (to a lesser extent) men's bodies in public spaces” (Gill, 2007a, p. 256). Furthermore, sexualization is a term used to contextualize the western sense that pornography is an influential facet of sexual representation (Gill, 2012). Examples from the documentary, such as a visual of the Playboy magazine reaffirm the influence of porn in women's representation. Discourse on sexualization places focus on the media's display of sexual imagery pertaining to women. Jackson \& Vares (2015) stated that "sexualization is expressly gendered" (p. 3). Women experience oversexualization through emphasis placed on their bodies.

The main characters argue that in media, women are seen as sexual objects for the male desire. Media sexualization includes reference toward the physical appearance of women as it relates sexual desirability (Ward et al., 2018). Historically, women have been portrayed as passive agents of sex (Gill, 2007a). Under preconceived notions of sexualization, women were characterized as being sexual subservient and inferior to males (Evans et al., 2010). Women were conceptualized as being responsible for sexual and emotional needs within relationships (Gill, 2007a). They were afforded the responsibility of managing the needs of men, without placing emphasis on their own pleasure (Gill, 2007a). Inversely, men were afforded agency in their sexuality. Men were characterized as being the aggressors, who seek sex with multiple partners. Contemporarily, there has been a shift in the representation of sexuality among women (Gill, 
2007a). Currently, media showcases a more autonomous portrayal of women's sexuality (Gill, 2007a). The shift in representation of sexuality holds significance as it establishes a new operation of sexual power (Gill, 2007a). Women are now establishing control over their sexuality and their sexual identities. Previously, women's sexuality was understood under the concept of objectification. The shift in women's sexual representation confirms a motion toward the subjectification of women's sexuality. The main characters of the documentary recognize this transition in media representation. Additionally, they use their personal experiences to actualize objectification and subjectification as independent concepts.

\section{Objectification}

Sexual objectification refers to "the reduction of a woman to her body, body parts, or sexual function, which are consequently viewed as instruments or as representing her entirely" (Vance et al., 2015, p. 570). Objectification is a form of oppression in which the bodies of a specific gender is sexualized and dehumanized. Objectification theorists, Frederickson \& Roberts (1997) stated that the "common thread running through all forms of sexual objectification is the experience of being treated as a body (or collection of body parts) valued predominantly for its use to (or consumption by) others" (p. 174). Moreover, scholars posit that objectification can be detrimental to a person's self-concept of humanity (Papadaki, 2007). When objectified, women are sexual props for the pleasure of men. The notion of objectification manifests negative frameworks.

Objectification is a concept with varying implications. Nussbaum (1995) identified seven notions that are found in the concept of objectification: instrumentality, denial of autonomy, inertness, fungibility, violability, ownership, and denial of subjectivity. She referred to instrumentality as the treatment of women as props for the use of a man's benefit. Additionally, 
women are denied autonomy in the process of objectification when men treat them as props; preventing women from using their sexuality to their own needs and benefits. She defined inertness as the act in which "the objectifier treats the object as lacking in agency, and perhaps also in activity" (p. 257). Fungibility refers to men treating women as objects that are interchangeable with one another. Violability occurs when men violate the boundaries of the women they objectify. Men often break boundaries of women and seek to reconfigure their integrity within objectification. In the film, Leia acknowledged that men are seen in a position of power within the objectification of women. Leia presented examples such as perfume brands which portray men as domineering over women. Ownership is illustrated through men treating women as if they are objects to own. Nussbaum (1995) concluded by certifying that the denial of subjectivity acknowledges the lack of compassion men afford to the experiences and feelings of the women they objectify. The seven notions of objectification recognize the negative connotations associated with treating women as objects.

The male gaze visualizes the oversexualization of womanhood. The male gaze is a form of objectification (Kozak et al., 2009). Mulvey (1989) describes the male gaze as the practice in film in which the active male peering at the body of the passive female. In the male gaze, men display a lustful glance toward the woman's body (Mulvey, 1989). The male gaze is inherently sexual (Mulvey, 1989). The male gaze occurs while engaging with media, or when men encounter women in the real world (Kozak et al., 2009). The male gaze is discussed within the documentary. The main characters give examples of the male gaze. Regina cites Transformers' (2007) portrayal of Megan Foxx, as an example of the male gaze. In one particular scene, the camera moves in a manner that prioritizes her body. The male gaze is submerged in sexual desire that a man has for a woman. 
Media facilitates a false conceptualization of women's sexuality. Previously, media had been known to exclusively objectify women (Gill, 2007a). Scholars argue that sexual objectification of women is a major facet of mainstream media (Ward et al., 2018). For example, advertisements of past have showcased scantily clad women who were sexually subservient to their male counterparts (Gill, 2007a). A shift has taken place recently, in which advertisers are targeting young women (Gill, 2007a). Currently, media showcases women to be autonomous of their sexuality. Advertisers are transitioning from the male gaze toward the agency of women's sexuality (Gill, 2003). Through media, culture, and society women have subjectified their sexuality.

\section{Subjectification}

Subjectification is conceptualized as the antithesis of objectification. In the documentary, Jennifer described subjectification as a counternarrative. Through being subjectified, an individual owns their being. Foucault (1997) defined the mode of subjectification as the means which people claim their own moral compass and obligations. He identified the mode of subjectification as a moment where "political power, glory, immortality, and beauty are all linked" (Foucault, 1997, p. 265). Sexual subjectification is a concept in which women claim agency and assert autonomy over their bodies and sexual imagery. Sexually subjectified women are active sexual beings that desire sex based on their own merits (Gill, 2003). In contrast to objectification, subjectified women no longer seek the approval of men (Gill, 2008). In the process of meeting their own sexual desires, women naturally gain the adoration of men (Gill, 2008). In recent years, women have experienced a shift from being sexual objects to being sexual subjects (Gill, 2003). The representation of women in media has progressed and allowed women to control the narratives of their sexuality. 
Some scholars argue that the subjectification of women serves to their detriment. Some perceive the contemporary subjectification of women to be a form of objectification (Attwood, 2011). It is argued that contemporary subjectification is a means of transitioning women into accepting their objectification (Attwood, 2011). Ashonti argued this point in the film. She argued that men have created what it means to be a woman; and while trying to be subjectified, women have accepted men's definition of objectification. This framework assumes that women have been tricked into subjectifying themselves. Gill (2003) argued that media portrays women as agents of their own sexuality, so that they can objectify themselves for others. Moreover, not every woman is afforded sexual agency (Gill, 2003). Only women who are young and attractive are seen with sexual subjectivity in media (Gill, 2003). Arguments against contemporary subjectification questions the similarity between subjectified and objectified standards of beauty (Gill, 2003). Women are still seen dressing in scantily clad clothing, as well as meeting the same body standards of objectifiable media (Gill, 2003). This counterargument to the subjectification of women's sexuality creates a dilemma in which agency is a falsehood. In the documentary, this is briefly referenced. Ashonti posits that for women to achieve full subjectification, they must redefine sexuality.

Sexualization is a main point in understanding the relationship between media and womanhood. It provides a frame in which the plight and triumphs of women can be understood. To critique the media's portrayal of women's sexuality requires a complete understanding of objectification and subjectification as concepts. Women are still sexualized in the media. However, it is untrue that the sexualization of women is universally the same. As Regina stated in the documentary, women are not monolithic. In post-feminism, the concept of intersectionality can be used to explore the differences of women, and the unique characteristics and 
predispositions women have. To fully understand sexualization, intersectionality must be traversed to highlight the different frequencies in which sexualization is experienced.

\section{Race and Womanhood}

Women from minority groups experience sexualization differently than white women. Intersectionality is a concept that traverses the different privileges and handicaps individuals experience based on variables such as race, ethnicity, gender, religion, and social class. Initially, intersectionality was used to reference the contentious and complex differences faced in the context of anti-prejudice and social movements (Cho et al., 2013). It also aimed to understand the structures in place based on similarities (Cho et al., 2013). Essentially, it observed the effects of monolithic mindsets within culture, and how they influenced the legal system, social justice, and epistemologies produced by disciplines (Cho et al., 2013). Recently, intersectionality has been used for feminist studies in reference to power structures that effect a woman's experience (Cho et al., 2013). Intersectionality analyzes how overlapping power relations effect social and individual circumstances in diverse societies (Collins \& Bilge, 2020). It is a concept used to gauge the human experience and the complexities that are shared within the human experiences (Collins \& Bilge, 2020). From understanding intersectionality, the acknowledgment of an individual's social identity reveals their experiences and opinions on gender (Shields, 2008). Intersectionality holds significance in the realm of post-feminism and feminism, because it places emphasis on the multifaceted nature of gender experiences. An individual's social status

in reference to their intersecting identities must be explored successfully to investigate gender as a concept (Shields, 2008). Intersectionality aims to destabilize the normativity associated with feminist discourse (Brah \& Phoenix, 2004). Intersectionality broadens the scope of feminist discourse from being associated to a monolithic identity (Brah \& Phoenix, 2004). Rather, 
intersectionality certifies that women each have different identities and social statuses that contribute to their experiences as women.

There are different layers that contribute to a broader understanding of intersectionality. The intersectional field of study is based around the various works and discourse on the subject (Cho et al., 2013). Precisely, intersectionality is understood as an assemblage of knowledge projects that are in constant reconfiguration based on the findings of each projects (Collins, 2015). In reference to its definitional dilemma, three focal points of which intersectionality are considered (Collins, 2015). Firstly, intersectionality is the object of investigation (Cho et al., 2013; Collins, 2015). From this point, the development of intersectionality is traversed to gauge what the true meaning and definitions of intersectionality is, are, or was (Cho et al., 2013). Secondly, bodies of work involving intersectionality observe the analytic prowess of intersectionality (Cho et al., 2013; Collins, 2015). This point attributes intersectionality to analyze the multifaceted nature of social identities as they are related to various topics (Cho et al., 2013). The documentary acknowledged the multifaceted nature of social identities by referencing race and gender, as they intersected. Regina, Ashonti, Leia, and Jennifer told their experiences of womanhood as women in minority groups. They each acknowledge the different forms of oppression that women in minority groups face in comparison to white women. Finally, intersectionality is used as a form of critical analysis, specifically in relation to social justice (Cho et al., 2013; Collins, 2015). In the race segment of the documentary, Ashonti, Regina, Leia, and Jennifer criticized the media portrayal of women in minority groups. They analyzed forms of media in which stereotypes are apparent. For example, Jennifer deconstructed a scene from Fast and the Furious: Tokyo Drift (2005) in which Japanese women were seen as sexual objects. In sum, intersectionality is used as a form of critical praxis to analyze reality (Cho et al., 2013; 
Collins, 2015). The three focal points of intersectionality advance intersectionality's ability to interconnect social structures and cultural representations (Collins, 2015). Essentially, it affords an opportunity to understand the different social identities observed within intersectionality. Intersectionality lends to post-feminism as a concept, because it identifies the relationships between gender, race, class, nationality, religion, and other social identities.

\section{Representation of Women in Minority Groups}

Racial identity plays a role in a woman's experience of sexualization. Racial formation theory adds to the concept of intersectionality (Collins, 2015). Racial formation theory relates to intersectionality. According to Collins (2015):

"Because it conceptualizes race as situated within the recursive relationship between social structures and cultural representations, racial formation theory conflates neither discourse about race (e.g., racial meanings, representations, and social identities) nor the power relations in which racial meanings are situated" (p. 4).

Racial formation theory acknowledges the multifaceted nature of issues related to race. It does not aim to establish a monolithic norm of the racial experience. Race is a key aspect in intersectionality. In the documentary, Abby acknowledged that women in minority groups face more prejudice than white women. Race and feminism intersect for women in minority groups.

Black feminism explores the challenges and triumphs of being black and being a woman. In America, Black feminism has been instrumental in the traversal of intersectionality in academia (Collins, 2015). The experiences of Black women and the frameworks of intersectionality are central to Black feminism as a praxis (Collins, 2000b). Black feminism acknowledges power structures and how they affect Black women (Collins, 2015). White males are the primary figures of power and control in western culture (Collins, 2000a). In the film, 
Regina and Ashonti criticized the societal roles and stereotypes that Black women are given. Regina specifically denounced mammy tropes, as contemporary tropes such as welfare queen. Regina denounced these stereotypes as harmful. She stated that how Black women are portrayed in media reflects how they are seen in reality. The purpose of Black feminism is to empower Black women through critical praxis of systems of oppression in intersecting social statuses and social identities (Collins, 2015). Broadly, Black feminism is significant because it imparts agency to a marginalized group that has historically taken a back seat in mainstream feminist discourse.

In critical analyses pertaining to sexualization, there has not been much focus on Black women, nor Asian women. Sexualization as a discourse focuses primarily on the sexualization of white women. In applying intersectionality, a critical analysis of sexualization can deconstruct the oppression that Black women and Asian women experience. Sexualization pertains to the objectification of women. Intersecting race and womanhood in acknowledgement of objectification would open a new depth of research to the realm of sexualization.

\section{Conclusion}

Post-feminism is a sensibility that aims to critique media and culture. While remaining feminist, the documentary seeks to use a post-feminist framework to deconstruct the portrayal of women in media. The representation of women in media plays a key role in the sexualization of women. Post-feminism provides a frame from which the sexualization of women can be acknowledged. Culturally, there has been a shift from the objectification of women toward the subjectification of women. The purpose of this documentary is to critique objectification and build upon subjectification as a concept. Through a post-feminist commentary on sexuality and the representation of women in media a better understanding of the communication and 
discourse behind women's sexuality can be met. Moreover, this documentary seeks to explore intersectionality as it relates to race and sexuality. An exploration of intersectionality provides a broader understanding of post-feminism and sexuality. To further understand post-feminism, the sexuality and the representation of white women and women of color, the follow research questions are posed:

$\mathrm{RQ}_{1}$ : How is sexuality performed across various experiences?

$\mathrm{RQ}_{2}$ : What role does media play in the hyper-sexualization of womanhood?

$\mathrm{RQ}_{3}$ : How does sexualization differ between white women and women of color?

$\mathrm{RQ}_{4}$ : How can the representation of women in media improve? 


\section{CHAPTER III: TREATMENT}

The sexualization of women in media and culture is deeply rooted. Throughout history, women have been portrayed as objects for men's desires. This documentary serves as an interrogation of women's representation in media and culture. Instead of a man objectifying women, a man seeks to understand their perspective and position. Rather taking the lead, filmmaker is a side character for the perspective of womanhood and women's representation in media. The filmmaker also serves as the narrator of the documentary. The women interviewed in this documentary are the main characters, serving as the eyes through which sexuality is framed. The main characters reference media related to women's sexuality. Video clips accompany the description of media that the main characters provide.

\section{The Introduction}

The film centers itself around five women, and their perspectives on women's sexuality and women's representation in media. The women in this documentary represent different perspectives of sexuality. Abby Bueter presented a progressive white woman's perspective on sexuality. Ashonti Phillips and Regina Sanders lend their voices toward the perspective of Black women traversing sexuality. Leia Atas and Jennifer Zheng participated in the film with the perspective of Asian women. They comment on the lack Asian women representation in media. Despite each woman sharing their experiences of sexuality within their race, they do not speak for their entire racial group. The point of their appearances is to highlight the multifaceted nature of womanhood, and to showcase that womanhood is not monolithic. Finally, women's representation and understanding of sexuality is not monolithic.

As the women introduce themselves, they will present their unique definitions of sexuality. This segment of the documentary personalizes the issue of sexualization in media. By 
personalizing the issue of hyper-sexualization, the documentary attaches emotion to the topic. The women who share their experiences will participate in a discourse about media, as well as culture. Their understanding of sexuality has been shaped by media they have encountered throughout their lives. The introduction is meant to set up the rest of the film by identifying the issue of women's representation in media.

\section{Objectification}

This section of the film seeks to analyze and deconstruct the offensive and disrespectful portrayals of women in media. The term objectification is presented with narration and conceptualized through the main characters' experiences. The main characters identify examples of objectification in women's representation. They highlight the shortcomings of objectification in media. Examples from TV series, commercials, films, and literature are examined. These examples will be shown to the viewer in cohesion with the main character's dialogue.

\section{Objectification of Women of Color}

Following the overall objectification of women, the documentary minimizes its scope to the objectification of women of color. The term intersectionality is established to gather a better understanding of the plight that Black and Asian women face. Ashonti, Regina, Leia, and Jennifer were the focus in this section of the documentary. They share their experiences of objectification as women of color. In prioritizing the experiences of marginalized groups, the documentary seeks to counteract the preconceived notion that only white feminism matters. The main characters acknowledge the differences in representation between white women and women of color. Shortcomings of the representation of women of color in media is highlighted. Furthermore, stereotypes that plague women in minority groups are deconstructed. The attacks women of color face from mainstream media and society are examined in this section. This 
segment is closed with observations involving contemporary portrayals of women of color in media.

\section{Subjectification}

A counternarrative to objectification is explored. Subjectification is examined by the main characters of the film, as an emerging concept. The main characters explore areas in which women are reclaiming their sexuality. Additionally, personal opinions on the topic of objectification are given. The comparison between objectification and subjectification is made. Examples of subjectification in media are gathered. Commentary on how women can subjectify themselves are made.

\section{Conclusion}

A look toward the future of women's representation in media is offered. The main characters talk about their hopes for the future of women's representation. Moreover, they acknowledge potential solutions to the harmful portrayals of women in media. The documentary closes with a hopeful look toward the future of women's representation in media and culture. Further conversation is given from the male narrator. The narrator argues in favor of progressive women's representation. Finally, the filmmaker encourages men to ally themselves with women, helping certify a future in which women have control over their representation in media. 


\section{REFERENCES}

Attwood, F. (2011). Through the looking glass? Sexual agency and subjectification online. In R. Gill \& C. Scharff (Eds.), New femininities: Postfeminism, neoliberalism, and subjectivity (pp. 52-67). Palgrave Macmillan. https://doi.org/10.1057/9780230294523_4

Brah, A. \& Phoenix, A. (2004). Ain’t I a woman? Revisiting intersectionality. Journal of International Women's Studies, 5(3), 75-86.

Brooks, A. (1997). Postfeminisms: Feminisms, cultural theory, and cultural forms. Routledge. https://doi.org/10.4324/9780203428894

Butler, J. (2013). For white girls only? Postfeminism and the politics of inclusion. Feminist Formations, 25(1), 35-58. https://doi.org/10.1353/ff.2013.0009

Cho, S., Crenshaw, K. W., \& McCall, L. (2013). Toward a field of intersectionality studies: Theory, applications, and praxis. Signs, 38(4), 785-810. https://doi.org/10.1086/669608

Collins, P. H. (2000a). Black feminist thought: Knowledge, consciousness, and the politics of empowerment ( $2^{\text {nd }}$ ed.). Routledge.

Collins, P. H. (2000b). Gender, black feminism, and black political economy. The ANNALS of the American Academy of Political and Social Science, 586(1), 41-53. https://doi.org/ $10.1177 / 000271620056800105$

Collins, P. H. (2015). Intersectionality's definitional dilemmas. The Annual Review of Sociology, 41(1), 1-20. https://doi.org/10.1146/annurev-soc-073014-112142

Collins, P. H., \& Bilge, S. (2020). Intersectionality (2 ${ }^{\text {nd }}$ ed.). Polity Press.

Evans, A., Riley, S., \& Shankar, A. (2010). Technologies of sexiness: Theorizing women's engagement in the sexualization of culture. Feminism \& Psychology, 20(1), 114-131. https://doi.org/10.1177/0959353509351854 
Faludi, S. (2009). Backlash: The undeclared war against american women. Broadway Books.

Foucault, M. (1997). Ethics: Subjectivity and truth (P. Rainbow, Ed.). New York Press. (Original work published 1954-1984)

Frederickson, B. L., \& Roberts, T. A. (1997). Objectification theory: Toward understanding women's lived experiences and mental health risks. Psychology of Women Quarterly, 21(2), 173-206. https://doi.org/10.1111/j.1471-6402.1997.tb00108.x

Gamble, S. (Ed.). (2004). The routledge companion to feminism and postfeminism. Routledge.

Gens, S., \& Brabon, B. A. (2009). Postfeminism: Cultural texts and theories. Edinburgh University Press.

Gill, R. (2003). From sexual objectification to sexual subjectification: The resexualisation of women's bodies in the media. Feminist Media Studies, 3(1), 100-106. https://doi.org/10.1080/1468077032000080158

Gill, R. (2007a). Gender and the media. Polity Press.

Gill, R. (2007b). Postfeminist media culture: Elements of a sensibility. European Journal of Cultural Studies, 10(2), 147-166. https://doi.org/10.1177/1367549407075898

Gill, R. (2008). Empowerment/sexism: Figuring female sexual agency in contemporary advertising. Feminism and Psychology, 18(1), 35-60. https://doi.org/10.1177/0959353507084950

Gill, R. (2012). The sexualisation of culture? Social and Personality Psychology Compass, 6(7), 483-498. https://doi.org/10.1111/j.1751-9004.2012.00433.x

Harvey, L., \& Gill, R. (2011). Spicing it up: Sexual entrepreneurs and the sex inspector. In R. Gill \& C. Scharff (Eds.), New femininities: Postfeminism, neoliberalism, and subjectivity (pp. 52-67). Palgrave Macmillan. https://doi.org/10.1057/9780230294523_4 
Jackson, S., \& Vares, T. (2015). 'Too many bad role models for us girls’: Girls, female pop celebrities, and 'sexualization'. Sexualities, 18(4), 480-489. https://doi.org/10.1177/1363460714550905

Jordan, A. (2016). Conceptualizing backlash: (UK) men's rights groups, anti-feminism, and postfeminism. Canadian Journal of Women and the Law, 28(1), 18-44. https://doi.org/10.3138/cjwl.28.1.18

Kozak, M., Frankenhauser, H., \& Roberts, T. A. (2009). Objects of desire: Objectification as a function of male sexual orientation. Psychology of Men \& Masculinity, 10(3), 225-230. https://doi.org/10.1037/a0016257

Lewis, P. (2014). Postfeminism, femininities and organizational studies: Exploring a new agenda. Organizational Studies, 35(12), 1845-1866. https://doi.org/10.1177/0170840614539315

Lotz, A. (2001). Postfeminist television criticism: Rehabilitating critical terms and identifying postfeminist attributes. Feminist Media Studies, 1(1), 105-121. https://doi.org/10.1080/14680770120042891

McRobbie, A. (2004). Post-feminism and popular culture. Feminist Media Studies, 4(3), 255264. https://doi.org/10.1080/1468077042000309937

Mulvey, L. (1989). Visual and other pleasures. Palgrave Macmillan.

Murray, G. (1997). Agonize, don’t organize: A critique of postfeminism. Current Sociology, 45(2), 37-47. https://doi.org/10.1177/001139297045002004

Nussbaum, M. C. (1995). Objectification. Philosophy Public Affairs, 24(4), 249-291. https://doi.org/10.1111/j.1088-4963.1995.tb00032.x 
Papadaki, E. (2007). Sexual objectification: From kant to contemporary feminism. Contemporary Political Theory, 6(3), 330-348.

https://doi.org/10.1057/palgrave.cpt.9300282

Projanksy, S. (2001). Watching rape: films and television in postfeminist culture. New York University Press.

Riley, S., Evans, A., Elliott, S., Rice, C., \& Marecek, J. (2017). A critical review of postfeminist sensibility. Social and Personality Psychology Compass, 11(12), e12367. https://doi.org/10.1111/spc3.12367

Shields, S. A. (2008). Gender: An intersectionality perspective. Sex Roles, 59(5-6), 301-311. https://doi.org/10.1007/s11199-008-9501-8

Vance, K., Sutter, M., Perrin, P. B., \& Heesacker, M. (2015). The media’s sexual objectification of women, rape myth acceptance, and interpersonal violence. Journal of Aggression, Maltreatment, \& Trauma, 24(5), 569-587, https://doi.org/10.1080/10926771.2015.1029179

Ward, L. M., Seabrook, R. C., Grower, P., Giaccardi, S., \& Lippman, J. R. (2018). Sexual object or sexual subject? Media use, self-sexualization, and sexual agency among undergraduate women. Psychology of Women Quarterly, 42(1), 29-43. https://doi.org/10.1177/0361684317737940 


\section{APPENDIX: THE NARRATION}

\section{Introduction}

"Entertainment media has been a constant in my life. Every TV Show, every movie, every song I have ever heard has left a lasting impression on me in some manner. I remember idolizing entertainment media. Everybody I saw on TV, I wanted to be them. Suffice to say that entertainment media has been my calling. It has influenced me throughout my life. It has socialized my manhood. Entertainment raised me to be who I am. Additionally, I argue that entertainment media has influenced everyone in some form. We are socialized to communicate in ways that reflect the entertainment we consume. As art often imitates reality, our reality has no choice but to embrace art. The things we see in media shape our understanding of reality. Those we see are often the basis for how we mold ourselves. All the above ring true to me. And while most of my heroes come from TV, there was always one that I saw daily in the real world, my mom. In watching her work hard to create opportunities for me, I recognize the difficulties that she faced. As any good son, I must concern myself with the issues that my mom once experienced. And as any good man, I must educate myself on the struggles that plague womanhood.

Since reality often reflects art, I feel that much of the struggle women experience stems from their representation in media. Typically, women in media are seen as props, or objects for the male desire. Largely, women have been oversexualized. Even further, I have noticed that women in minority groups have been dehumanized and disenfranchised more than white women. The representation of women in media reinforces how they are treated in reality. However, recently social movements led by women are aiming to counteract the hyper-sexualization of womanhood in media and culture. We are entering a zeitgeist where women control their narrative. Nevertheless, an education on women's sexuality is still necessary.

My pursuit of knowledge has brought a few research questions on the topic of women's sexuality and women's representation: How is sexuality performed across various experiences? What role does media play in the hyper-sexualization of womanhood? How does sexualization differ between white women and women of color? And finally, how can the representation of women in media improve?

Before I can answer these questions, I must understand the perspective of women. And as a man, it is not my job to define, nor communicate the different experiences of womanhood and sexuality. Therefore, my interest led me to interviewing a few phenomenal women who sought to educate me on their experiences of womanhood, representation, and their defining of sexuality."

\section{Objectification}

"Men have always been the purveyors of media representation. Everything is seen from our perspective. We control the manners in which women are represented. We are in the position of power. I have seen firsthand, the dehumanization of womanhood in media. Due to the constant prioritization of the male perspective, women have been seen as survivors of the male desire. Their representation is one in which independence is nonexistent. They are not seen as people with wants and needs of their own, rather objects for the purpose of satisfying the male gaze. The male gaze is a concept that fits into the overarching discourse regarding the objectification of women in media." 


\section{Race and Womanhood}

"Despite women sharing the brunt of objectification, their experiences are not monolithic. Throughout American history, Black women, Asian women, and Latinas have experienced a greater degree of marginalization than white women. In identifying as women in minority groups, they face double the prejudice in comparison. They are seen as fetishes, rather than people. They are treated as subordinates to the yearns of male dominance. Additionally, the abuses that they face go unnoticed. The media representation of women in minority groups reinforces the harmful notion that they are lesser than men, as well their white woman counterparts."

\section{Subjectification}

“We cannot discount the progress of women's representation. In recent years, we have seen women fight for power on a social and artistic level. The representation of womanhood is undergoing a shift, where women are controlling their narrative; subjectifying their livelihoods and the experiences attached to them. No further should women be identified as objects for the male gaze. Women are to be seen as how they want to be seen. Subjects of their own inclinations."

\section{The Future}

"As a principle, subjectification is sparking philosophical muses regarding women's sexuality. In learning about subjectification, I have a deeper understanding of men's role in women's representation. How are women to achieve full independence from the male perspective, if the structures being used are inherently male-born? The answer does not lie with me, it lies in women. The path toward equity in media representation starts with engaging the concepts that build our understanding of society and culture. And while, it is a complex concept, Subjectification is paving the way toward prosperity in women's representation. As a counternarrative, subjectification encourages dialogue and discourse regarding the characterization of womanhood. It affords primacy to the woman's perspective. And personally, I am in favor of embracing such presentation."

\section{Closing}

"In speaking with my friends and colleagues, I have been enlightened. My pursuit of knowledge brought me to a better understanding of women, as well as their representation in media. No longer should they be props or objects. But phenomenally, they are seen as women.

Despite writing, editing, and directing this documentary, it is not my intention to control, or dictate the portrayal and understanding of womanhood. My goal in this project was to educate. Furthermore, myself, nor my friends are seeking to man hate. We are not seeking to further divide the sexes with our critical discourse. We just want to see more. We deserve better as a culture. We just want the representation of women in media to be better.

Media representation should reflect a narrative in which women are seen how they desire. To any men watching this, it is our time to step aside. Let women tell their stories. Let them create. Let them own their spaces. To do this, we as men should revoke the ownership of their sexuality. Who are we to tell the stories of womanhood? Who are we to construct narratives surrounding their representation? As men, we are often fixed on notions of control. It is time we concede. 
In the end, I hope we progress toward a future in which the portrayal of women in media is authentic. We can counteract objectification, we can counteract dehumanization, we can counteract the mischaracterization of women in media. It starts with listening." 